1 Pharmaceutical Payments to Japanese Certificated Hematologists: A Retrospective

2 Analysis of Personal Payments from Pharmaceutical Companies between 2016 and

$3 \quad 2019$

4

5 Authors:

6 Eiji Kusumi, MD ${ }^{1 \dagger}$; Anju Murayama ${ }^{2,3,{ }^{*},} ;$ Sae Kamamoto ${ }^{2,4, \dagger}$; Moe Kawashima ${ }^{2,5}$;

7 Makoto Yoshida ${ }^{2}$; Hiroaki Saito, MD, $\mathrm{PhD}^{6}$; Toyoaki Sawano, $\mathrm{MD}, \mathrm{PhD}^{7}$; Erika

8 Yamashita $^{2}$; Tetsuya Tanimoto, $\mathrm{MD}^{8}$; Akihiko Ozaki, $\mathrm{MD}, \mathrm{PhD}^{9}$

9

$10 \dagger$ Authors equally contributed to this study

$11{ }^{*}$ Corresponding author

12

13 Affiliations:

$14{ }^{1}$ Department of Internal Medicine, Navitas Clinic Shinjuku, Shinjuku-ku, Tokyo, Japan 
$15 \quad{ }^{2}$ Medical Governance Research Institute, Minato-ku, Tokyo, Japan

$16{ }^{3}$ Tohoku University School of Medicine, Sendai City, Miyagi, Japan

$17{ }^{4}$ Hamamatsu University School of Medicine, Hamamatsu, Shizuoka, Japan

$18{ }^{5}$ Fukushima Medical University, Fukushima city, Fukushima, Japan

$19{ }^{6}$ Department of Gastroenterology, Sendai Kosei Hospital, Sendai City, Miyagi, Japan

$20{ }^{7}$ Department of Surgery, Jyoban Hospital of Tokiwa Foundation, Iwaki City, Fukushima,

21 Japan

$22 \quad{ }^{8}$ Department of Internal Medicine, Navitas Clinic, Tachikawa City, Tokyo, Japan

$23{ }^{9}$ Department of Breast Surgery, Jyoban Hospital of Tokiwa Foundation, Iwaki City,

24 Fukushima, Japan

25

26 Correspondence

27 Anju Murayama

28 Medical Governance Research Institute, Minato-ku, Tokyo, 1087505, Japan 
29 Telephone: 81-90-6321-6996

30 Email address: ange21tera@gmail.com

31 Word count: 3267 words

32 Number of Tables: 2

33 Number of Figures: 3

\section{Funding sources:}

37 This study was funded in part by the Medical Governance Research Institute. This non-

38 profit enterprise receives donations from pharmaceutical companies, including Ain

39 Pharmacies, Inc., other organizations, and private individuals. This study also received

40 support from the Tansa (formerly known as the Waseda Chronicle), an independent non-

41 profit news organization dedicated to investigative journalism. None of the entities

42 providing financial support for this study contributed to the design, execution, data

43 analyses, or interpretation of study findings and the drafting of this manuscript. 


\section{Abstract}

45 Background: A growing and significant financial relationship exist between physicians

46 and pharmaceutical companies. However, little is known about the characteristics and

47 trends of personal payments from pharmaceutical companies to hematologists. This

48 study was aimed to evaluate the financial relationship between hematology specialists

49 and pharmaceutical companies in Japan between 2016 and 2019.

50 Methods: Descriptive analyses were performed to evaluate personal payments from 92

51 major pharmaceutical companies to all board-certificated hematologists in Japan.

52 Furthermore, trend of payments over four years were evaluated by generalized

53 estimating equations.

54 Results: Among the 4,183 hematology specialists, 2,706 (64.7\%) received a total of

55 US $\$ 36,291,434$ ( $¥ 3,955,766,292)$. The personal payments were worth $\$ 13,411$ (standard

56 deviation: $\$ 34,856$ ) on average, with a median of $\$ 2,471$ (Interquartile range:

$57 \$ 851 \square \$ 9,677)$ over the four-year period, respectively. Only the top $10 \%$ of specialists

58 accounted for $76.8 \%$ of the total payments. The average payment values constantly

59 increased from $\$ 4,259$ to $\$ 5,574$ between 2016 and 2019 , with a significant mean 
medRxiv preprint doi: https://doi.org/10.1101/2022.01.17.22269284; this version posted January 18, 2022. The copyright holder for this preprint

(which was not certified by peer review) is the author/funder, who has granted medRxiv a license to display the preprint in perpetuity.

It is made available under a CC-BY-NC-ND 4.0 International license.

60 annual increase rate of $11.2 \%$ (95\%CI: $9.1 \% \square 13.4 \%$ ). The proportion of hematology

61 specialists with payments also slightly increased by $1.8 \%$ (95\%CI: $0.6 \% \square 3.0 \%$ ) per

62 year.

63 Conclusions: Most Japanese board-certified hematology specialists received substantial

64 personal payments. These payments are becoming increasingly more prevalent and

65 greater among hematology specialists.

66 


\section{Main text}

\section{Introduction}

69 Although collaboration between healthcare professionals, patients, and pharmaceutical

70 companies has played a significant role in the development of novel drugs and a better

71 understanding of diseases (ref.[1, 2]), proper management of conflicts of interest (COIs)

72 is currently one of the most fundamental concerns of all healthcare professionals

73 (ref.[3]), as financial COIs between healthcare sectors and pharmaceutical companies

74 could jeopardize patient-centered care. Indeed, the financial relationship between the

75 healthcare sector and pharmaceutical companies might affect physician prescribing

76 patterns (ref.[4-6]), recommendations in clinical guidelines (ref.[7-11]), and conducting

77 and reporting of clinical research (ref.[12, 13]). These concerns and motivation to

78 increase transparency in financial COIs has led to the creation of transparency initiatives

79 worldwide (ref.[14, 15]), including in Japan. The Japan Pharmaceutical Manufacturers

80 Association (JPMA), the largest pharmaceutical trade organization in Japan, requires all

81 JPMA member companies from 2013 onwards to voluntarily publish all payments made

82 to healthcare professionals and healthcare organizations (ref.[16]). 
84 In the field of hematology, a wide variety of therapeutic strategies and novel therapies

85 (ref.[17-19]), including chemotherapy, targeted therapy, and hematopoietic stem cell

86 transplantation for the treatment of hematological cancers, have brought significant

87 therapeutic benefits to patients and attracted considerable attention from pharmaceutical

88 companies, resulting in intense marketing by pharmaceutical companies. The financial

89 relationships of hematologists and oncologists with pharmaceutical companies as

90 compared to other specialists have increased in recent years (ref.[20-22]). In addition,

91 Japanese hematology guideline authors receive an average of $\$ 25,471$ to $\$ 49,693$ in

92 personal payments from pharmaceutical companies (ref.[23]), one of the largest average

93 payments among guideline authors in several specialties (ref.[11, 24, 25]). Considering

94 the current pharmaceutical marketing strategy and the sizable evidence indicating that

95 pharmaceutical marketing could influence physician prescription patterns (ref.[5, 26,

96 27]), the elucidation and proper management of the financial relationships between

97 pharmaceutical companies and hematologists are important. 
99 This study aims to elucidate the prevalence of board-certified hematologists receiving

100 payments from pharmaceutical companies, the magnitude of the payments, and the

101 payment trend in recent years.

102

103 Methods

104 Participants

105 This study considered all hematologists certified by the Japanese Society of Hematology,

106 as of October 10, 2021, as hematology specialists. The Japanese Society of Hematology

107 was established in 1937 and is the most prestigious and largest medical professional

108 society in hematology in Japan, with 7,744 members as of October 8, 2021. The

109 Japanese Society of Hematology is the sole professional medical society authorized to

110 certify hematology specialists in Japan. The list of names of the hematology specialists

111 is publicly available on the society's webpage and was last updated on July 7, 2021

112 (http://www.jshem.or.jp/modules/senmoni/). 


\section{Certification of hematologists by the Japanese Society of Hematology}

115 The Japanese Society of Hematology is the sole society in Japan authorized to certify

116 hematology specialists. As of October 2021, to be certificated as a hematology specialist,

117 physicians are required to meet all of the following six requirements: (1) submission of

118 clinical records for 15 inpatients as an attending physician, including at least three cases

119 of erythrocyte disease, three cases of leukocyte disease, two cases of thrombosis and

120 hemostasis, and one case of immunology and blood transfusion; (2) must be listed as the

121 first author of at least two academic articles or conference presentations; (3) must have

122 completed at least six years of clinical practice training after having acquired a medical

123 license and at least three years of specialized training in hematology at an institution

124 accredited by the Japanese Society of Hematology; (4) must have a board certification

125 in internal medicine issued by the Japanese Society of Internal Medicine or in pediatrics

126 issued by the Japan Pediatric Society; (5) must be a registered member of the Japanese

127 Society of Hematology for at least three years; and (6) must clear the written

129 Hematology. 


\section{Data collection}

132 The names, affiliations, and addresses of all hematology specialists were disclosed and

133 collected from the Japanese Society of Hematology webpage on October 10, 2021.

134 Payment data of all healthcare professionals and healthcare organizations regarding

135 lecturing, writing, and consulting were collected for the period 2016-2019 from 92

136 pharmaceutical companies belonging to the JPMA. After collecting the payment data, a

137 single unified database was developed, as described previously (ref.[24, 28]). JPMA

138 requires the member companies to disclose only the payment concerning lecturing,

139 writing, and consulting, along with the individuals' names and affiliations; therefore,

140 these payment categories could be analyzed on an individual specialist basis. Personal

141 payments, such as those for lecturing, writing, and consulting, are directly and widely

142 paid to specialists by pharmaceutical companies. (ref.[6, 28-31]) Considering the nature

143 of payments, only the personal payments concerning lecturing, writing, and consulting

144 were included in this study. 
146 We scanned for specialist names in the payment database and extracted the payment

147 data from the payment database of hematology specialists. The extracted data included

148 the recipient names, affiliations, monetary amount, number of payment cases, payment

149 category, and names of the respective pharmaceutical companies. To remove payment

150 data of different persons with similar names in the database, we checked and compared

151 the affiliations, affiliation addresses, and recipient specialties between the data from the

152 Japanese Society of Hematology and the pharmaceutical companies For payments to

153 specialists whose affiliations reported by the pharmaceutical company differed from

154 those reported by the society, we manually searched the name of the specialists on the

155 internet and collated other data from official institutional webpages and other sources to

156 verify their identity. We also excluded payments that could not be verified from the

157 analysis. The detailed procedure has been previously described (ref.[24, 28]).

158 Furthermore, the lists of drugs newly approved for hematological diseases between

1592015 and 2020 were collected from the webpage of the Pharmaceuticals and Medical

160 Devices Agency, which is the official agency for reviewing drugs in Japan. 


\section{Analysis}

163 Descriptive analyses of payment values and the number of cases were performed per

164 specialist and per pharmaceutical company. Average and median payments, cases, and

165 number of companies making payments per specialist were calculated based only on the

166 number of specialists receiving payments each year, as in other studies. (ref.[20, 29, 30,

167 32]) As several companies such as Shire Japan and Baxalta did not disclose the number

168 of payment cases, the payments from these companies were excluded from the analysis

169 of the number of cases, while the payment values were included in the analysis. To

170 examine the concentration of payments to individual specialists, the Gini index and

171 shares of the value of payments held by the top $1 \%, 5 \%, 10 \%$, and $25 \%$ of specialists

172 were calculated. The Gini index ranges from 0 to 1 , and the greater the Gini index, the

173 greater the disparity in the distribution of payments on a specialist basis, as mentioned

174 previously. (ref.[24, 25]) Payment distribution was also examined geographically.

176 Further, to examine the trend of payments from pharmaceutical companies to specialists

177 from 2016 to 2019, the population-averaged generalized estimating equation negative 
178 binomial regression model for the trend of payment value and the linear generalized

179 estimating equation model log linked with binomial distribution for the trend of

180 numbers of specialists with payments were used. The relative ratios of the average

181 annual increase in payments per specialist to the number of specialists with payments

182 were used to report the results.

183 The year of payments was set as an independent variable, and the proportion of

184 physicians receiving payments, number of payments, and payment values were set as

185 dependent variables. (ref.[20, 33, 34]) As several pharmaceutical companies

186 disaffiliated from the JPMA and newly joined the JPMA, among all 92 companies, there

187 were 18 companies without payment data over the four years. Thus, the average and

188 median payments for each year and the trend of payments were calculated based on

189 payments from all 92 companies and 74 companies with payment data for the four years

190 between 2016 and 2019.

192 To adjust for inflation and to make the payment value comparable, Japanese yen (¥) was

193 converted into US dollars (\$) using the 2019 average monthly exchange rate of $¥ 109.0$ 
194 per \$1. All analyses were conducted using Microsoft Excel (version 16.0; Microsoft

195 Corp.) and Stata (version 15; StataCorp).

197 Ethical approval

198 This study was approved by the Ethics Committee of the Medical Governance Research

199 Institute. As this study is a retrospective analysis of publicly available information,

200 informed consent was waived and direct contact with the society was allowed by the

201 Ethics Committee of the Medical Governance Research Institute.

\section{Overview of payments}

205 We identified 4,183 hematology specialists certified by the Japanese Society of

206 Hematology as of October 10, 2021. Our payment database recorded 1,474,653

207 payment cases and $\$ 996,291,009$ ( $¥ 108,595,720,027)$ in total monetary value from 92

208 pharmaceutical companies between 2016 and 2019. 
209 Of the 4,183 specialists, 2,706 (64.7\%) received a total of US\$36,291,434

210 (¥3,955,766,292) corresponding to 47,863 cases from $71(77.2 \%)$ pharmaceutical

211 companies between 2016 and 2019 (Table 1). The payment cases and values to the

212 hematology specialists occupied $3.2 \%$ and $3.6 \%$ of total cases and values, respectively.

213 A total of $82.5 \%(\$ 29,951,526)$ of the total payments were for lecturing, followed by

$21413.5 \%$ from consulting $(\$ 4,890,255), 3.9 \%$ from writing $(\$ 1,398,729)$, and $0.1 \%$ from

215 others $(\$ 50,924)$. The average monetary value per case was $\$ 758$, ranging from $\$ 736$ for

216 lecturing to $\$ 922$ for consulting.

\section{$218 \quad$ Payments per specialists}

219 The hematology specialists received personal payments worth $\$ 13,411$ (Standard

220 deviation (SD): $\$ 34,856$ ) on average and a median of $\$ 2,471$ (Interquartile range (IQR):

$221 \$ 851 \square \$ 9,677)$ over the four-year period. The average and median number of cases over

222 the four years was 17.7 (SD: 35.9) and 5.0 (IQR:2.0 $\square$ 17.0) cases per specialist,

223 respectively. The average number of companies making payments per specialist was 5.5

224 (SD: 5.2; median: 4.0; IQR: 2.0 $\square$ 8.0; and range: 1.0 $\square 32.0$ ) (Table 1). 
225 For the concentration of payments, $4.2 \%$ and $1.9 \%$ of hematology specialists received

226 more than $\$ 50,000$ and $\$ 100,000$, respectively. The Gini index for the four-year

227 cumulative payments per specialist was 0.856 , indicating that the distribution of the

228 total payments per specialist was highly skewed. Top $1 \%, 5 \%, 10 \%$ and $25 \%$ of

229 specialists occupied $26.0 \%$ (95\% confidence interval (CI): $23.1 \% \square 28.9 \%), 61.0 \%$

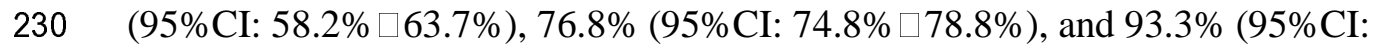

$23192.6 \% \square 94.0 \%$ ) of total payments, respectively (Figure 1).

\section{Payment trend between 2016 and 2019}

234 Regarding the payment trend of all 71 companies through the four years, annual total

235 payments increased from $\$ 7,700,346(839,337,686)$ in 2016 to $\$ 10,279,218$

236 (¥1,120,434,752) in 2019. In addition, payments per specialist and the number of

237 specialists with payments increased from \$4,259 (SD: \$9,291) and 1,808 (43.2\%) in

2382016 to $\$ 5,574$ (SD: $\$ 11,688)$ and $1,844(44.1 \%)$ in 2019 , respectively. The relative

239 annual increase rates were $1.112(95 \% \mathrm{CI}: 1.091 \square 1.134 ; \mathrm{p}<0.001)$ in payments per

240 specialist and 1.018 (95\%CI: $1.006 \square 1.030$; $\mathrm{p}=0.003$ ) for specialists with payments, 
241 indicating that the payment values and number of specialists increased by $11.2 \%$

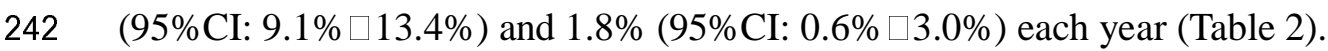

243 Of 74 companies collecting payments data over four years, there were 64 companies

244 with the four-years payment data. Limiting to the payments from the 64 companies,

245 both the average and median payment values also constantly increased from $\$ 4,259$

246 (SD: \$9,291) and \$1,241 (IQR: \$511 $\square$ \$3,442) to \$5,536 (SD: \$11,557) and \$1,633

247 (IQR: $\$ 613 \square \$ 4,760$ ) between 2016 and 2019, respectively. The relative annual change

248 rate for payments per specialist and number of specialists with payments also

249 significantly increased by $11.2 \%$ (95\%CI: 9.1\% $\square 13.4 \%)$ and $1.8 \%$ (95\%CI:

$250 \quad 0.6 \% \square 3.0 \%)$, respectively, each year.

251 Furthermore, the annual change rate was higher among those with greater four-year

252 cumulative payments, such as those receiving $\$ 1,000-\$ 10,000$ at $12.8 \%$ (95\% CI:

$2539.5 \% \square 16.1 \% ; \mathrm{p}<0.001), \$ 10,000-\$ 50,000$ at $13.7 \%$ (95\%CI: $10.4 \% \square 17.1 \% ; \mathrm{p}<$

2540.001 ), and $\$ 50,000-\$ 100,000$ at $13.8 \%$ (95\%CI: 8.1\% $\square 19.8 \%$; p < 0.001), while those

255 with payments of more than $\$ 100,000$ had a lower annual increase rate of $8.1 \%$

$256 \quad$ (95\%CI: $4.2 \% \square 11.1 \% ; \mathrm{p}<0.001)$. 


\section{$258 \quad$ Payment by pharmaceutical companies}

259 Among 71 pharmaceutical companies making payments to specialists, payments from

260 the top 10 companies accounted for $70.8 \%$ of the total payments $(\$ 25,236,750)$

261 between 2016 and 2019 (Figure 2). The payment types for each of the top 10 paying

262 companies are shown in Figure 3. Four among the 10 companies, namely, Takeda

263 Pharmaceutical, Chugai Pharmaceutical, Janssen Pharmaceutical, and Novartis Pharma,

264 increased their payments to hematology specialists. A total of 673 drugs were newly

265 approved and introduced between 2015 and 2020 in Japan. Among these indicators, 211

$266(31.4 \%)$ were from the top 10 companies, and of these, 52 drugs $(24.6 \%)$ were for

267 hematological diseases (Supplemental Material 1).

Geographical payment distribution

270 Geographical differences were observed in the distribution of the number of hematology

271 specialists. Based on the prefecture, payments from pharmaceutical companies

272 (Supplemental Material 2A) to hematology specialists per one million of the population 
273 ranged from 18.2 in Aomori Prefecture to 64.4 in Kyoto (Supplemental Material 2B).

274 The average payment values per specialist were the highest in Tochigi Prefecture

$275(\$ 15,806)$ and lowest in Kumamoto Prefecture $(\$ 3,178)$ (Supplemental Material 2D).

276

\section{Discussion}

278 This study demonstrated that 3.6\% $(\$ 36,291,434)$ of total personal payments

279 concerning lecturing, consulting, and writing from all major pharmaceutical companies

280 to healthcare professionals were distributed to board certified hematology specialists,

281 who accounted for $1.3 \%(4,183$ out of 327,210$)$ of total physicians in Japan, according

282 to the latest survey by the Japanese Ministry of Health, Labor and Welfare in

283 2018(ref.[35]). Among all Japanese board-certified hematology specialists, 64.7\%

284 received an average of $\$ 13,411$ in personal payments between 2016 and 2019, with an

285 annual average increase rate of $11.2 \%$. To the best of our knowledge, this is the first

286 study to assess the distribution and the trend of financial relationships between board-

287 certified hematologists and pharmaceutical companies. Although our study could have

288 limitations such as underreported payments due to the limited category of personal 
289 payments in Japan, there were important similarities and differences between our

290 findings and those of the previous studies.

292 Previous studies in the United States demonstrated that $80.2 \%$ of hematologists and

293 oncologists received general payments averaging $\$ 6,166(\$ 2,055$ in one year) between

2942015 and 2017. (ref.[31]) Another study by Marshall et al. reported that $63.0 \%$ of

295 medical oncologists, including pediatric hematologists/oncologists and

296 hematologist/oncologists, received \$7,750 in average general payment in 2014 (ref.[22]),

297 and, in the six years between 2014 and $2019,84.6 \%(13,190$ out of 15,585$)$ of medical

298 oncologists received $\$ 38,601(6,434$ in one year) in average general payment per

299 physician (ref.[20]). Another study by Ozaki et al. evaluated pharmaceutical payments

300 among Japanese board-certified oncologists, and they found that $70.6 \%$ of certified

301 oncologists received an average of $\$ 4,982$ in annual personal payments. (ref.[28]) Our

302 study showed that the average personal payments ranged from $\$ 4,259$ to $\$ 5,574$ and the

303 proportion of (mention specialist type) specialists with payments ranging from $40.2 \%$ to

$30445.3 \%$ in a single year were fewer than those in the United States and less than the 
305 average proportion of Japanese hematologists and oncologists.

306

307 Meanwhile, in other specialties, the average total payments per physician, such as

308 general, research, and ownership payments, were $\$ 907$ among pediatricians in 2014

309 (ref.[36]); \$4,183 (\$2,091 per year) among psychiatrists between 2016 and 2017

310 (ref.[37]); \$3,433 (\$1,144 in one year) in general payments among obstetricians and

311 gynecologists between 2013 and 2015 (ref.[38]); from \$1,795 in 2014 to \$2,227 in 2017

312 among board certificated nephrologists (ref.[39]); \$3,260 among orthopedic surgeons in

3132013 (ref.[40]); \$4,177 among dermatologists in 2014 (ref.[30]); \$25,960 (\$5,191 per

314 year) among ophthalmologists between 2013 and 2017 (ref.[41]); \$16,914 (\$5,638 per

315 year) among cardiologists between 2014 and 2016 (ref.[42]); \$38,664 (\$6,444 per year)

316 among rheumatologists between 2014 and 2019 (ref.[43]); and \$7,263 among

317 neurologists in 2015. (ref.[44]) Comparing these findings, the Japanese board

318 certificated hematologists might have similar or greater financial relationships with

319 pharmaceutical companies than other specialists in the United States and Japan. 
321 This study showed that only a very small proportion of hematology specialists received

322 the majority of personal payments from pharmaceutical companies. As previous studies

323 have found (ref.[25, 30, 41-43]), pharmaceutical companies have concentrated their

324 payments on a small number of physicians with extensive clinical and research

325 experience. These specialists, or "key opinion leaders," (ref.[45]) who had substantial

326 financial relationships with pharmaceutical companies, played a significant role in

327 delivering information about newer drugs, novel findings from clinical trials, and drug

328 related risks, to healthcare professionals at conferences for continuing medical

329 education sponsored by pharmaceutical companies (ref.[46]). We should note that while

330 the financial relationships of specialists with pharmaceutical companies might help to

331 rapidly unroll novel drugs with greater benefits (ref.[26, 46]), it could also increase

332 healthcare costs when the specialists prescribe brand name drugs (ref.[4, 47]) or drugs

333 whose benefits are unproven (ref.[48, 49]).

335 Further, regarding the trend of payments, we found that total and average payments

336 increased significantly every year, with an $11.2 \%$ yearly increase in average payments. 
337 This trend of increasing payments to physicians was also observed among oncologists

338 in the United States. Marshall et al. found that since the launch of the US Open Payment

339 Database, the total and annual average payment value per physician declined by $-1.7 \%$

340 and $-0.6 \%$, respectively (ref.[34]). However, pharmaceutical companies increasingly

341 prioritized the payments to hematologists and oncologists, with a $4.9 \%$ and $1.7 \%$ annual

342 increase in total value and average payments (ref.[20]). Furthermore, although the

343 disclosure of personal payments from pharmaceutical companies to healthcare

344 professionals and healthcare organizations was intended to improve transparency rather

345 than curb the financial relationships, our findings indicate that disclosure itself did not

346 sufficiently decrease the financial relationships between pharmaceutical companies and

347 hematology specialists in Japan, as corroborated by previous studies in the United States.

349 Companies' payment trends would provide further understanding of the increase in the

350 average payments and proportion of specialists with payments among Japanese

351 hematology specialists. The top 10 companies expanded their indications in the field of

352 hematology, ranging from one to 11 new indications per company. While the payment 
353 from Celgene, the largest paying company, remained stable, four companies, namely,

354 Takeda Pharmaceutical, Chugai Pharmaceutical, Janssen Pharmaceutical, and Novartis

355 Pharma, remarkably increased their payments to the hematology specialists between

3562016 and 2019. As a drug target, multiple myeloma accounted for the largest proportion

357 (17 out of 52 indications), which may explain the recent trend of increasing payments.

358 In fact, all the companies mentioned above, except Chugai Pharmaceutical, have

359 developed newly approved drugs for multiple myeloma. In addition to multiple

360 myeloma, Novartis made the largest total payments of $\$ 1,323,027$ in 2019 , when the

361 chimeric antigen receptor T cells, tisagenlecleucel (KYMRIAH), was granted approval

362 for the treatment of B-cell precursor acute lymphoblastic leukemia and large B-cell

363 lymphoma and was priced at about 32 million JPY (equal to about 300,000 USD),

364 covered by the Japanese public health insurance. Regarding Chugai Pharmaceutical,

365 emicizumab (HEMLIBRA, approved in 2018 for congenital blood coagulation factor 8

366 deficiency) may account for the increased payment.

368 This study has several limitations. First, our payment database was constructed by 
369 manually collecting payment data from 92 pharmaceutical companies and repeatedly

370 crosschecking it for any errors by two or more persons. Despite careful and repeated

371 checks, the inclusion of errors by our study team and pharmaceutical companies

372 reporting data could not be ruled out. However, the publicly disclosed payment database

373 (https://db.tansajp.org/en) welcomed inquiries from the recipients of payments and

374 pharmaceutical companies reporting any errors in the data, and the payment database

375 was checked and revised for each inquiry. These procedures minimized the inclusion of

376 errors in this study. In addition, payment data concerning meals, education, travel, and

377 accommodations were not disclosed with the individual names of recipients by

378 pharmaceutical companies in Japan (ref.[16]). Thus, these payment data are not

379 analyzable. Considering that such payment categories like meals were the most

380 prevalent among physicians (ref.[30, 42, 48]), this study underreports the prevalence

381 and magnitude of financial relationships between hematology specialists and

382 pharmaceutical companies in Japan. However, this study highlights the magnitude and

383 prevalence of financial relationships between pharmaceutical companies and Japanese

384 hematologists. 
386 In conclusion, this study found that between 2016 and 2019, 64.7\% of Japanese board-

387 certified hematology specialists received an average of $\$ 13,411$ in personal payments as

388 the reimbursement for lecturing, consulting, and writing. Only a small proportion of

389 hematology specialists received the vast majority of payments from pharmaceutical

390 companies. Furthermore, these personal payments from pharmaceutical companies were

391 increasingly more prevalent and greater among Japanese hematology specialists.

\section{Acknowledgement}

395 The authors thank the Tansa (formerly known as Waseda Chronicle) for providing

396 payment data and Editage (www.editage.com) for English language editing. Also, we

397 appreciate Mr. Souto Nagano, an undergraduate student at the University of Tokyo

398 Faculty of Letters; Mr. Kohki Yamada, a medical student at the Osaka University

399 School of Medicine; and Ms. Megumi Aizawa, a graduate student at the Department of

400 Industrial Engineering and Economics, School of Engineering, Tokyo Institute of 
401 Technology, for their dedicated contribution on collecting and cross-checking the

402 payment data.

403 This study was funded in part by the Medical Governance Research Institute. This non-

404 profit enterprise receives donations from pharmaceutical companies, including Ain

405 Pharmacies, Inc., other organizations, and private individuals. This study also received

406 support from the Tansa (formerly known as the Waseda Chronicle), an independent non-

407 profit news organization dedicated to investigative journalism. None of the entities

408 providing financial support for this study contributed to the design, execution, data

409 analyses, or interpretation of study findings and the drafting of this manuscript.

410 For the financial conflicts of interest, Dr. Kusumi received personal fees from Otsuka

411 Pharmaceutical Co. Ltd outside the scope of the submitted work. Dr. Saito received

412 personal fees from TAIHO Pharmaceutical Co. Ltd outside the scope of the submitted

413 work. Drs. Ozaki and Tanimoto received personal fees from Medical Network Systems

414 outside the scope of the submitted work. Dr. Tanimoto also received personal fees from

415 Bionics Co. Ltd, outside the scope of the submitted work. Regarding non-financial

416 conflicts of interest among the study authors, all are engaged in ongoing research 
417 examining financial and non-financial conflicts of interest among healthcare

418 professionals and pharmaceutical companies in Japan. Individually, Anju Murayama,

419 Hiroaki Saito, Toyoaki Sawano, Tetsuya Tanimoto, and Akihiko Ozaki have contributed

420 to several published studies assessing conflicts of interest and quality of evidence

421 among clinical practice guideline authors in Japan and the United States. Among their

422 previous articles, the authors have self-cited several articles in this study to gain deeper

423 insights and explain the context of financial conflicts of interest among healthcare

424 professionals in Japan. Dr. Kusumi was a hematology specialist board certificated by

425 the Japanese Society of Hematology. The other authors have no example conflicts of

426 interest to disclose.

428 Author Contributions:

429 EK was responsible for study concept, data collection, statistical analysis, and drafting

430 and reviewing of the manuscript. AM was responsible for study concept and design,

431 data collection, statistical analysis, and drafting and reviewing of the manuscript. SK

432 was responsible for study concept and design, data collection, statistical analysis, and 
433 drafting of the manuscript. MK contributed to study concept, data collection, and

434 drafting of the manuscript. MY contributed to study concept, data collection, and

435 drafting of the manuscript. HS contributed to study concept and design, drafting of the

436 manuscript, and critically reviewing of the manuscript. TS contributed to study concept

437 and design, drafting of the manuscript, and critically reviewing of the manuscript. EY

438 contributed to study concept and design, and critically reviewing of the manuscript.

439 TT conducted to study concept and design, drafting of the manuscript, and study

440 supervision. AO conducted study concept and design, statistical analysis, drafting of the

441 manuscript, and study supervision. All authors had full access to all the data in the study

442 and take responsibility for the integrity of the data and the accuracy of the data analysis. 


\section{Competing interests:}

445 For the financial conflicts of interest, Dr. Kusumi received personal fees from Otsuka

446 Pharmaceutical Co., Ltd outside the scope of the submitted work. Dr. Saito received

447 personal fees from TAIHO Pharmaceutical Co. Ltd outside the scope of the submitted

448 work. Drs. Ozaki and Tanimoto received personal fees from Medical Network Systems

449 outside the scope of the submitted work. Dr. Tanimoto also received personal fees from

450 Bionics Co. Ltd, outside the scope of the submitted work. Regarding non-financial

451 conflicts of interest among the study authors, all are engaged in ongoing research

452 examining financial and non-financial conflicts of interest among healthcare

453 professionals and pharmaceutical companies in Japan. Individually, Anju Murayama,

454 Hiroaki Saito, Toyoaki Sawano, Tetsuya Tanimoto, and Akihiko Ozaki have contributed

455 to several published studies assessing conflicts of interest and quality of evidence

456 among clinical practice guideline authors in Japan and the United States. Among their

457 previous articles, the authors have self-cited several articles in this study to gain deeper

insights and explain the context of financial conflicts of interest among healthcare

459 professionals in Japan. Dr. Kusumi was a hematology specialist board certificated by 
medRxiv preprint doi: https://doi.org/10.1101/2022.01.17.22269284; this version posted January 18, 2022. The copyright holder for this preprint (which was not certified by peer review) is the author/funder, who has granted medRxiv a license to display the preprint in perpetuity.

It is made available under a CC-BY-NC-ND 4.0 International license .

460 the Japanese Society of Hematology. The other authors have no example conflicts of

461 interest to disclose.

462

463

464 


\section{References}

466 1. Wouters OJ, McKee M, Luyten J. Estimated Research and Development Investment

467 Needed to Bring a New Medicine to Market, 2009-2018. JAMA 2020;323(9):844-853.

468 2. Rubin EH, Gilliland DG. Drug development and clinical trials-the path to an

469 approved cancer drug. Nature Reviews Clinical Oncology 2012;9(4):215-222.

470 3. Medicine AFABol, Medicine A-AFACoP-ASol, European Federation of Internal M.

471 Medical professionalism in the new millennium: a physician charter. Ann Intern Med

472 2002;136(3):243-6.

4734 4. DeJong C, Aguilar T, Tseng C-W, et al. Pharmaceutical Industry-Sponsored Meals

474 and Physician Prescribing Patterns for Medicare Beneficiaries. JAMA Internal Medicine

$475 \quad 2016 ; 176(8): 1114-1122$.

4765 5. Mitchell AP, Trivedi NU, Gennarelli RL, et al. Are Financial Payments From the

477 Pharmaceutical Industry Associated With Physician Prescribing? : A Systematic Review. Ann

478 Intern Med 2020; 10.7326/m20-5665.

4796 Hartung DM, Johnston K, Cohen DM, et al. Industry Payments to Physician

480 Specialists Who Prescribe Repository Corticotropin. JAMA Network Open 2018;1(2):e180482-

$481 \mathrm{e} 180482$.

4827 Nejstgaard $\mathrm{CH}$, Bero L, Hrobjartsson A, et al. Association between conflicts of

483 interest and favourable recommendations in clinical guidelines, advisory committee reports,

484 opinion pieces, and narrative reviews: systematic review. BMJ 2020;371:m4234.

485 8. Murayama A, Ozaki A, Saito H, et al. Are Clinical Practice Guideline for Hepatitis C

486 by the American Association for the Study of Liver Disease and Infectious Diseases Society of

487 America Evidence-based? Financial Conflicts of Interest and Assessment of Quality of Evidence

488 and Strength of Recommendations. Hepatology 2021;n/a(n/a).

4899 . Johnson L, Stricker RB. Attorney General forces Infectious Diseases Society of

490 America to redo Lyme guidelines due to flawed development process. J Med Ethics

$491 \quad 2009 ; 35(5): 283-8$.

492 10. Coyne DW. Influence of Industry on Renal Guideline Development. Clinical Journal

493 of the American Society of Nephrology 2007;2(1):3-7.

494 11. Hashimoto T, Murayama A, Mamada H, et al. Evaluation of Financial Conflicts of

495 Interest and Drug Statements in the Coronavirus Disease 2019 Clinical Practice Guideline in

496 Japan. Clin Microbiol Infect 2021; 10.1016/j.cmi.2021.11.019. 
497 12. Lundh A, Lexchin J, Mintzes B, et al. Industry sponsorship and research outcome.

498 Cochrane Database Syst Rev 2017;2(2):MR000033.

499 13. Wilson JM. Lessons learned from the gene therapy trial for ornithine

500 transcarbamylase deficiency. Mol Genet Metab 2009;96(4):151-7.

501 14. Pham-Kanter G. Act II of the Sunshine Act. PLoS Med 2014;11(11):e1001754.

502 15. Silverman E. Everything you need to know about the Sunshine Act. BMJ : British

503 Medical Journal 2013;347:f4704.

504 16. Ozaki A, Saito H, Senoo Y, et al. Overview and transparency of non-research

505 payments to healthcare organizations and healthcare professionals from pharmaceutical

506 companies in Japan: Analysis of payment data in 2016. Health Policy 2020;124(7):727-735.

507 17. Zhou J, Vallejo J, Kluetz P, et al. Overview of Oncology and Hematology Drug

508 Approvals at US Food and Drug Administration Between 2008 and 2016. JNCl: Journal of the

509 National Cancer Institute 2019;111(5):449-458.

510 18. Mato AR, Shah NN, Jurczak W, et al. Pirtobrutinib in relapsed or refractory B-cell

511 malignancies (BRUIN): a phase 1/2 study. Lancet 2021;397(10277):892-901.

512 19. Awasthi R, Pacaud L, Waldron E, et al. Tisagenlecleucel cellular kinetics, dose, and

513 immunogenicity in relation to clinical factors in relapsed/refractory DLBCL. Blood Advances

514 2020;4(3):560-572.

515 20. Tarras ES, Marshall DC, Rosenzweig K, et al. Trends in Industry Payments to

516 Medical Oncologists in the United States Since the Inception of the Open Payments Program,

5172014 to 2019. JAMA Oncology 2021;7(3):440-444.

518 21. Pokorny AMJ, Bero LA, Moynihan R, et al. Industry payments to Australian medical

519 oncologists and clinical haematologists: a cross-sectional analysis of publicly-available

520 disclosures. Intern Med J 2020;n/a(n/a).

521 22. Marshall DC, Moy B, Jackson ME, et al. Distribution and Patterns of Industry-Related

522 Payments to Oncologists in 2014. JNCl: Journal of the National Cancer Institute 2016;108(12).

523 23. Harada K, Ozaki A, Saito H, et al. Financial payments made by pharmaceutical

524 companies to the authors of Japanese hematology clinical practice guidelines between 2016

525 and 2017. Health Policy 2021;125(3):320-326.

526 24. Murayama A, Ozaki A, Saito H, et al. Pharmaceutical company payments to

527 dermatology Clinical Practice Guideline authors in Japan. PLoS One 2020;15(10):e0239610.

528 25. Yamamoto K, Murayama A, Ozaki A, et al. Financial conflicts of interest between

529 pharmaceutical companies and the authors of urology clinical practice guidelines in Japan. Int 
530 Urogynecol J 2021;32(2):443-451.

531 26. Mitchell AP, Winn AN, Dusetzina SB. Pharmaceutical Industry Payments and

532 Oncologists' Selection of Targeted Cancer Therapies in Medicare Beneficiaries. JAMA Internal

533 Medicine 2018;178(6):854-856.

534 27. Mitchell AP, Winn AN, Lund JL, et al. Evaluating the Strength of the Association

535 Between Industry Payments and Prescribing Practices in Oncology. The Oncologist

536 2019;24(5):632-639.

537 28. Ozaki A, Saito H, Onoue Y, et al. Pharmaceutical payments to certified oncology

538 specialists in Japan in 2016: a retrospective observational cross-sectional analysis. BMJ Open

$5392019 ; 9(9): \mathrm{e} 028805$.

540 29. Tringale KR, Marshall D, Mackey TK, et al. Types and Distribution of Payments From 541 Industry to Physicians in 2015. JAMA 2017;317(17):1774-1784.

542 30. Feng H, Wu P, Leger M. Exploring the Industry-Dermatologist Financial Relationship:

543 Insight From the Open Payment Data. JAMA Dermatol 2016;152(12):1307-1313.

544 31. Inoue K, Blumenthal DM, Elashoff D, et al. Association between physician

545 characteristics and payments from industry in 2015-2017: observational study. BMJ Open

$546 \quad 2019 ; 9(9): e 031010$.

547 32. Tringale KR, Hattangadi-Gluth JA. Types and Distributions of Biomedical Industry

548 Payments to Men and Women Physicians by Specialty, 2015. JAMA Intern Med

549 2018;178(3):421-423.

550 33. Marshall DC, Tarras ES, Rosenzweig K, et al. Trends in Financial Relationships

551 Between Industry and Radiation Oncologists Versus Other Physicians in the United States from

5522014 to 2018. International Journal of Radiation Oncology ${ }^{*}$ Biology ${ }^{*} P h y s i c s ~ 2021 ; 109(1): 15-25$.

553 34. Marshall DC, Tarras ES, Rosenzweig K, et al. Trends in Industry Payments to

554 Physicians in the United States From 2014 to 2018. JAMA 2020;324(17):1785-1788.

555 35. Ministry of Health LaW. Survey of Physicians, Dentists and Pharmacists 2018. In:

556 Ministry of Health, Labour and Welfare; 2018.

557 36. Parikh K, Fleischman W, Agrawal S. Industry Relationships With Pediatricians:

558 Findings From the Open Payments Sunshine Act. Pediatrics 2016;137(6):e20154440.

559 37. Rhee TG, Wilkinson ST. Exploring the Psychiatrist-Industry Financial Relationship:

560 Insight from the Open Payment Data of Centers for Medicare and Medicaid Services. Adm

561 Policy Ment Health 2020;47(4):526-530.

562 38. Muffly TM, Giamberardino WL, Guido J, et al. Industry Payments to Obstetricians 
563 and Gynecologists Under the Sunshine Act. Obstetrics \& Gynecology 2018;132(1).

564 39. Pakanati AR, Kovvuru K, Thombre V, et al. Industry Payments to Nephrologists in

565 the United States. Cureus 2021;13(8):e17057.

566 40. Cvetanovich GL, Chalmers PN, Bach BR, Jr. Industry Financial Relationships in

567 Orthopaedic Surgery: Analysis of the Sunshine Act Open Payments Database and Comparison

568 with Other Surgical Subspecialties. JBJS 2015;97(15).

569 41. Slentz DH, Nelson CC, Lichter PR. Characteristics of Industry Payments to

570 Ophthalmologists in the Open Payments Database. JAMA Ophthalmology 2019;137(9):1038-

5711044.

572 42. Annapureddy A, Murugiah K, Minges KE, et al. Industry Payments to Cardiologists.

573 Circulation: Cardiovascular Quality and Outcomes 2018;11(12):e005016.

574 43. Putman MS, Goldsher JE, Crowson CS, et al. Industry Payments to Practicing US

575 Rheumatologists, 2014-2019. Arthritis \& Rheumatology 2021;73(11):2138-2144.

576 44. Ahlawat A, Narayanaswami P. Financial relationships between neurologists and

577 industry. Neurology 2019;92(21):1006.

$57845 . \quad$ Moynihan R. Key opinion leaders: independent experts or drug representatives in

579 disguise? BMJ 2008;336(7658):1402-3.

$580 \quad 46 . \quad$ Inoue K, Figueroa JF, DeJong C, et al. Association Between Industry Marketing

581 Payments and Prescriptions for PCSK9 (Proprotein Convertase Subtilisin/Kexin Type 9)

582 Inhibitors in the United States. Circulation: Cardiovascular Quality and Outcomes

583 2021;14(5):e007521.

584 47. Yeh JS, Franklin JM, Avorn J, et al. Association of Industry Payments to Physicians

585 With the Prescribing of Brand-name Statins in Massachusetts. JAMA Internal Medicine

586 2016;176(6):763-768.

587 48. Inoue K, Tsugawa $\mathrm{Y}$, Mangione $\mathrm{CM}$, et al. Association between industry payments

588 and prescriptions of long-acting insulin: An observational study with propensity score matching.

589 PLOS Medicine 2021;18(6):e1003645.

590 49. Goupil B, Balusson F, Naudet F, et al. Association between gifts from pharmaceutical

591 companies to French general practitioners and their drug prescribing patterns in 2016:

592 retrospective study using the French Transparency in Healthcare and National Health Data

593 System databases. BMJ 2019;367:16015. 
medRxiv preprint doi: https://doi.org/10.1101/2022.01.17.22269284; this version posted January 18, 2022. The copyright holder for this preprint (which was not certified by peer review) is the author/funder, who has granted medRxiv a license to display the preprint in perpetuity.

It is made available under a CC-BY-NC-ND 4.0 International license. 
medRxiv preprint doi: https://doi.org/10.1101/2022.01.17.22269284; this version posted January 18, 2022. The copyright holder for this preprint (which was not certified by peer review) is the author/funder, who has granted medRxiv a license to display the preprint in perpetuity.

It is made available under a CC-BY-NC-ND 4.0 International license.

596 Table 1. Summary of personal payments from pharmaceutical companies to

597 hematology specialists certified by the Japanese Society of Hematology between

$598 \quad 2016$ and 2019

599

Variables

Total

Payment values, US\$ (\%)

$36,291,434(3.6)$

Cases, n (\%)

$47,863(3.2)$

Companies, n (\%)

71 (77.2)

Average per specialist (SD)

Payment values, US\$

$13,411(34,856)$

Cases, $n$

$17.7(35.9)$

Companies, $\mathbf{n}$

$5.5(5.2)$

Median per specialist (IQR)

Payment values, US\$

$2,471(851 \square 9,677)$

Cases, $n$

$5(2 \square 17)$ 
Companies, $\mathbf{n}$

\section{Range}

Payment values, US\$

Cases, $\mathbf{n}$

Companies, $\mathbf{n}$

Physicians with specific payments, $n(\%)$
$4(2 \square 8)$

$46 \square 528,038$

$\mathbf{0} \square \mathbf{4 8 7}$

$\mathbf{0} \square 32$
Any payments

Payments $>$ US\$500

Payments $>$ US $\$ 1,000$

Payments >US\$5,000

Payments $>$ US\$10,000

Payments $>$ US\$50,000

Payments $>$ US\$100,000

Gini index

Category of payments

\section{Lecturing}

Payment value, US\$ (\%)
$2,706(64.7)$

2,392 (57.2)

1,947 (46.6)

980 (23.4)

$666(15.9)$

175 (4.2)

78 (1.9)

0.856 
medRxiv preprint doi: https://doi.org/10.1101/2022.01.17.22269284; this version posted January 18, 2022. The copyright holder for this preprint (which was not certified by peer review) is the author/funder, who has granted medRxiv a license to display the preprint in perpetuity.

\section{It is made available under a CC-BY-NC-ND 4.0 International license .}

Cases, n (\%)

40,686 (85.0)

\section{Consulting}

Payment value, US\$ (\%)

4,890,255 (13.5)

Cases, $\mathrm{n}(\%)$

$5,302(11.1)$

\section{Writing}

Payment value, US\$ (\%)

$1,398,729$ (3.9)

Cases, n (\%)

$1,816(3.8)$

Other

Payment value, US\$ (\%)

$50,924(0.1)$

Cases, n (\%)

59 (0.1)

600

601 
604

\begin{tabular}{|c|c|c|c|c|c|c|c|}
\hline Variables & 2016 & 2017 & 2018 & 2019 & $\begin{array}{l}\text { Relative yearly change } \\
\text { ratio }(95 \% \mathrm{CI})\end{array}$ & $P$ value & $\begin{array}{c}\text { Four-years combined } \\
\text { total }\end{array}$ \\
\hline \multicolumn{8}{|l|}{$\begin{array}{l}\text { All pharmaceutical } \\
\text { companies }\end{array}$} \\
\hline $\begin{array}{l}\text { Total payments, } \\
\text { US\$ (¥) }\end{array}$ & 7,700,346 & $(901,080,935)$ & $(1,094,912,919)$ & $10,279,218$ & $\square$ & $\square$ & $(3,955,766,292)$ \\
\hline $\begin{array}{l}\text { Average payments } \\
\text { (SD), US\$ }\end{array}$ & $4,259(9,291)$ & $4,918(10,677)$ & $5,306(11,403)$ & $5,574(11,688)$ & $1.112(1.091 \square 1.134)$ & $<0.001$ & $13,411(34,856)$ \\
\hline Median payments & $1,241(511 \square 3,442)$ & $1,343(525 \square 4,087)$ & $1,504(525 \square 4,628)$ & $1,629(613 \square 4,839)$ & & & 2,471 (851ロ9,677) \\
\hline
\end{tabular}




\section{(IQR), US\$}

Payment range, US\$

$46 \square 106,834$

$46 \square 167,828$

$46 \square 148,942$

$52 \square 140,947$

$\square$

$\square$

$46 \square 528,038$

Physicians with

specific payments, $n$

(\%)

\begin{tabular}{|c|c|c|c|c|c|c|c|}
\hline Any payments & $1,808(43.2)$ & $1,681(40.2)$ & $1,893(45.3)$ & $1,844(44.1)$ & $1.018(1.006 \square 1.030)$ & 0.003 & $2,706(64.7)$ \\
\hline Payments > US\$500 & $1,444(34.5)$ & $1,373(32.8)$ & $1,577(37.7)$ & $1,570(37.5)$ & $1.040(1.027 \square 1.054)$ & $<0.001$ & $2,374(56.8)$ \\
\hline $\begin{array}{l}\text { Payments } \\
>\text { US\$1,000 }\end{array}$ & $1024(24.5)$ & $998(23.9)$ & $1,178(28.2)$ & $1159(27.7)$ & $1.055(1.039 \square 1.071)$ & $<0.001$ & $1,945(46.5)$ \\
\hline $\begin{array}{l}\text { Payments } \\
>\text { US\$5,000 }\end{array}$ & $331(7.9)$ & $360(8.6)$ & $454(10.9)$ & $446(10.7)$ & $1.117(1.088 \square 1.146)$ & $<0.001$ & $975(23.3)$ \\
\hline $\begin{array}{l}\text { Payments } \\
>\text { US\$10,000 }\end{array}$ & $187(4.5)$ & $208(5.0)$ & $239(5.7)$ & $253(6.0)$ & $1.109(1.071 \square 1.149)$ & $<0.001$ & $660(15.8)$ \\
\hline Payments & $15(0.36)$ & $20(0.5)$ & $26(0.6)$ & $24(0.57)$ & $1.169(1.033 \square 1.323)$ & 0.014 & $172(4.1)$ \\
\hline
\end{tabular}

Payments

$15(0.36)$

$20(0.5)$

$26(0.6)$

$24(0.57)$

$1.169(1.033 \square 1.323)$

0.014 


\section{$>$ US\$50,000}

\begin{tabular}{|c|c|c|c|c|c|c|c|}
\hline $\begin{array}{l}\text { Payments } \\
>\text { US\$100,000 }\end{array}$ & $2(0.048)$ & $2(0.048)$ & $4(0.096)$ & $5(0.12)$ & $1.420(0.940 \square 2.147)$ & 0.096 & $75(1.8)$ \\
\hline Gini index & 0.876 & 0.885 & 0.870 & 0.872 & $\square$ & $\square$ & 0.856 \\
\hline $\begin{array}{l}\text { Pharmaceutical } \\
\text { companies with 4-years } \\
\text { payment data }^{a}\end{array}$ & & & & & & & \\
\hline Total payments, & $7,700,346$ & $8,266,798$ & $10,045,073$ & $10,142,157$ & $\square$ & $\square$ & $35,972,679$ \\
\hline US\$ (¥) & $(838,940,102)$ & $(884,814,326)$ & $(1,091,772,525)$ & $(11,05,495,102)$ & & & $(3,921,022,055)$ \\
\hline $\begin{array}{l}\text { Average payments } \\
\text { (SD), US\$ }\end{array}$ & $4,259(9,291)$ & $4,918(10,677)$ & $5,306(11,403)$ & $5,536(11,557)$ & $1.112(1.091 \square 1.134)$ & $<0.001$ & $13,333(34,685)$ \\
\hline $\begin{array}{l}\text { Median payments } \\
\text { (IQR), US\$ }\end{array}$ & $1,241(511 \square 3,442)$ & $1,343(525 \square 4,087)$ & $1,504(523 \square 4,628)$ & $1,633(613 \square 4,760)$ & & & $2,470(851 \square 9,500)$ \\
\hline Payment range, US\$ & $46 \square 106,834$ & $46 \square 167,828$ & $0 \square 148,942$ & $0 \square 137,882$ & $\square$ & $\square$ & $46 \square 528,038$ \\
\hline
\end{tabular}


Physicians with

specific payments, $\mathbf{n}$

(\%)

\begin{tabular}{|c|c|c|c|c|c|c|c|}
\hline Any payments & $1,808(43.2)$ & $1,681(40.2)$ & $1,893(45.3)$ & $1,844(44.1)$ & $1.018(1.006 \square 1.030)$ & 0.003 & $2,698(64.5)$ \\
\hline Payments >US\$500 & $1,444(34.5)$ & $1,373(32.8)$ & $1,577(37.7)$ & $1,570(37.5)$ & $1.040(1.027 \square 1.054)$ & $<0.001$ & $2,383(57.0)$ \\
\hline $\begin{array}{l}\text { Payments } \\
\text { >US\$1,000 }\end{array}$ & $1,024(24.5)$ & 998 (23.9) & $1,178(28.2)$ & $1,159(27.7)$ & $1.055(1.039 \square 1.071)$ & $<0.001$ & $1,938(46.3)$ \\
\hline $\begin{array}{l}\text { Payments } \\
\text { >US\$5,000 }\end{array}$ & $331(7.9)$ & $360(8.6)$ & 454 (10.9) & $446(10.7)$ & $1.117(1.088 \square 1.146)$ & $<0.001$ & $973(23.3)$ \\
\hline $\begin{array}{l}\text { Payments } \\
>\text { US\$10,000 }\end{array}$ & $187(4.5)$ & $208(4.8)$ & $239(5.7)$ & $253(6.0)$ & $1.109(1.071 \square 1.149)$ & $<0.001$ & $659(15.8)$ \\
\hline $\begin{array}{l}\text { Payments } \\
>\text { US\$50,000 }\end{array}$ & $15(0.36)$ & $20(0.48)$ & $26(0.62)$ & $24(0.57)$ & $1.169(1.033 \square 1.323)$ & 0.014 & $174(4.2)$ \\
\hline $\begin{array}{l}\text { Payments } \\
\text { >US\$100,000 }\end{array}$ & $2(0.048)$ & $2(0.048)$ & $4(0.096)$ & $5(0.12)$ & $1.420(0.940 \square 2.147)$ & 0.096 & $77(1.8)$ \\
\hline
\end{tabular}


Gini index

2019

608 
Figure 1. Concentration of payment to individual hematology specialists 


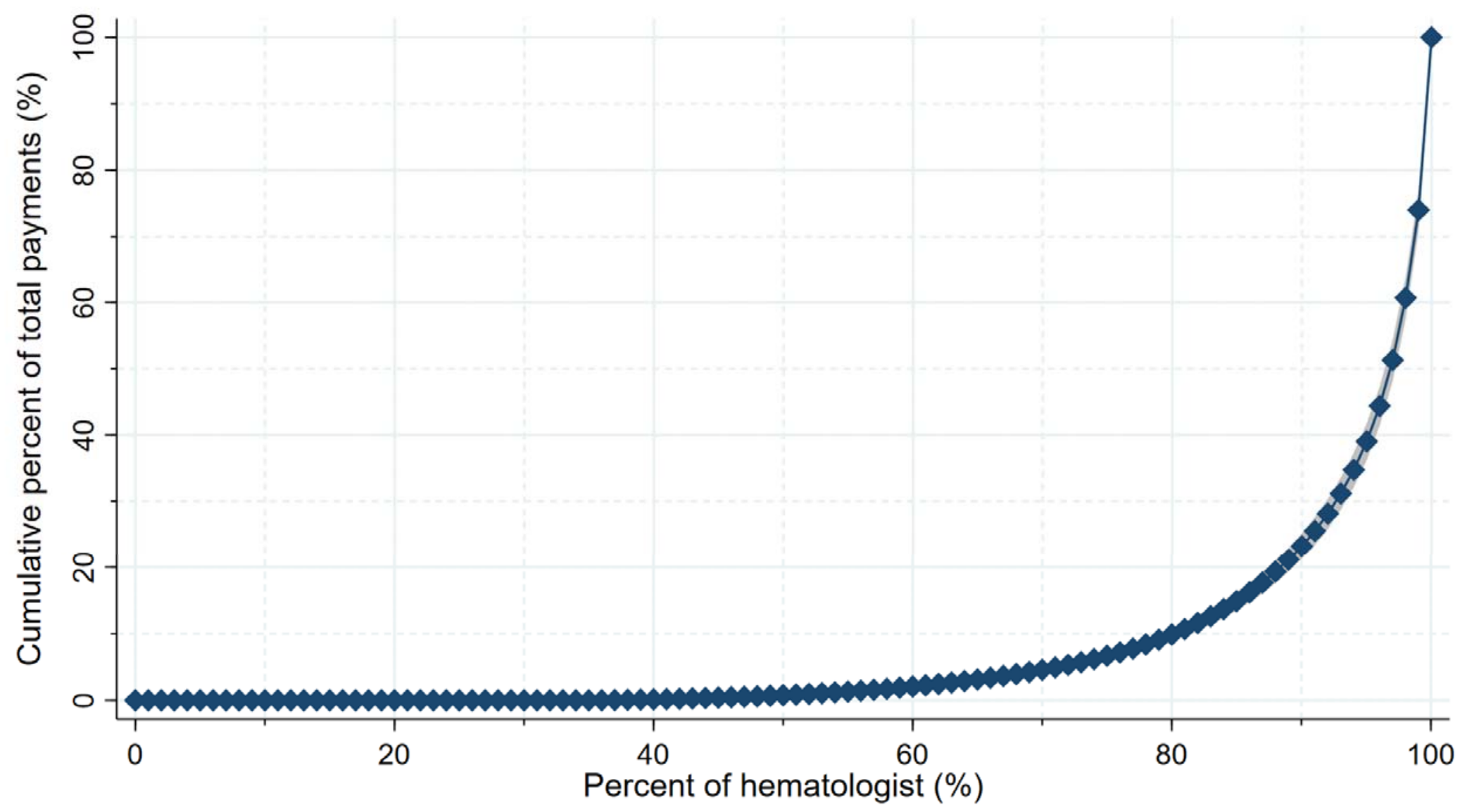




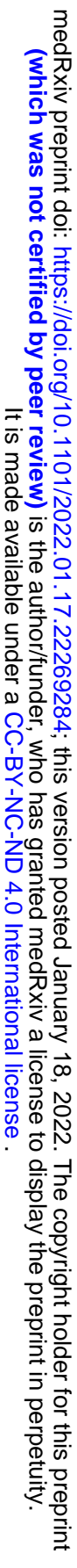


Figure 2. Total payments from top 10 largest paying pharmaceutical companies between 2016 and 2019 


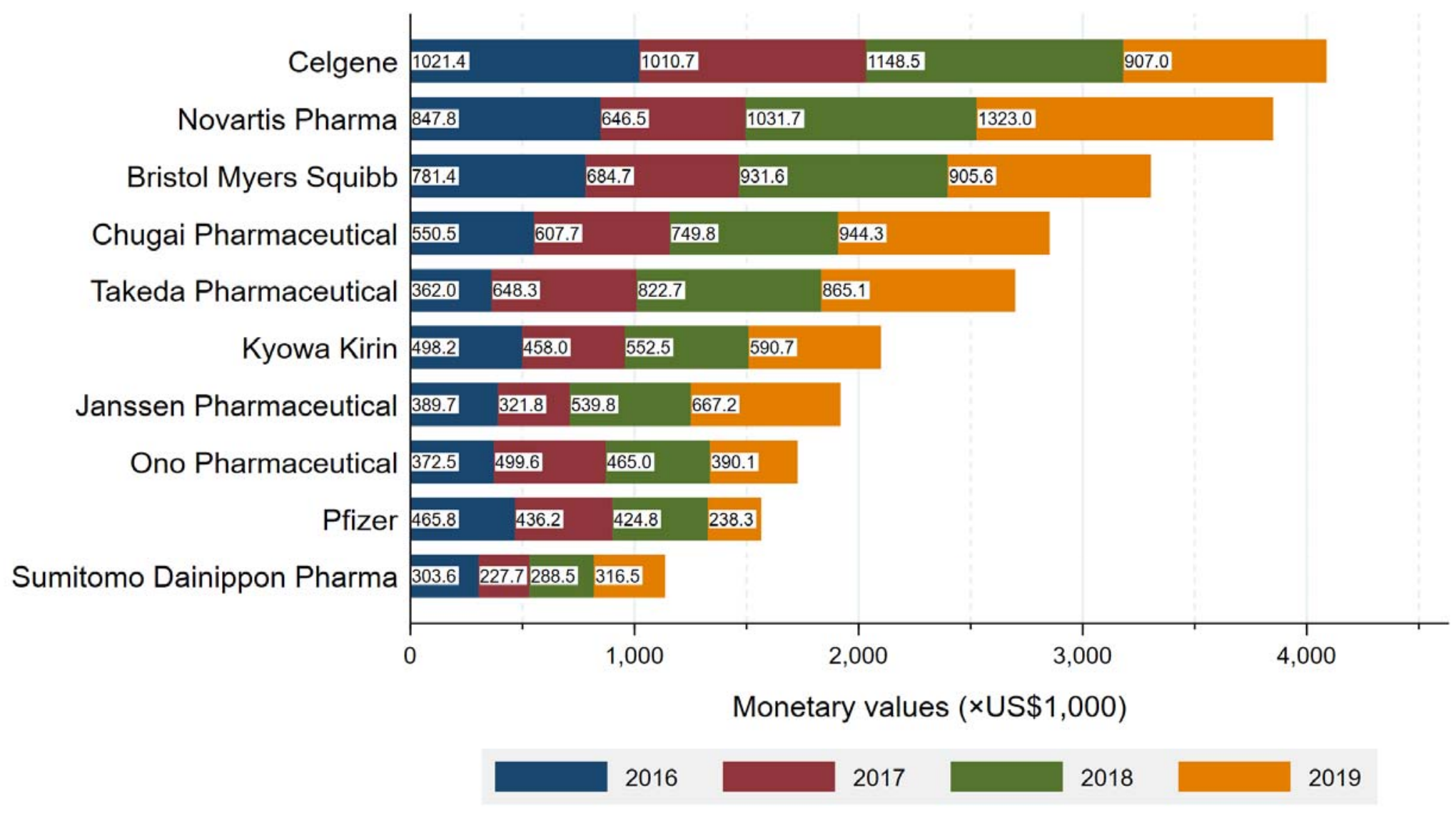




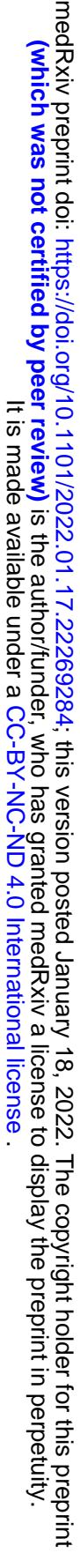


Figure 3. Category and distribution of payments by top 10 largest paying pharmaceutical companies 


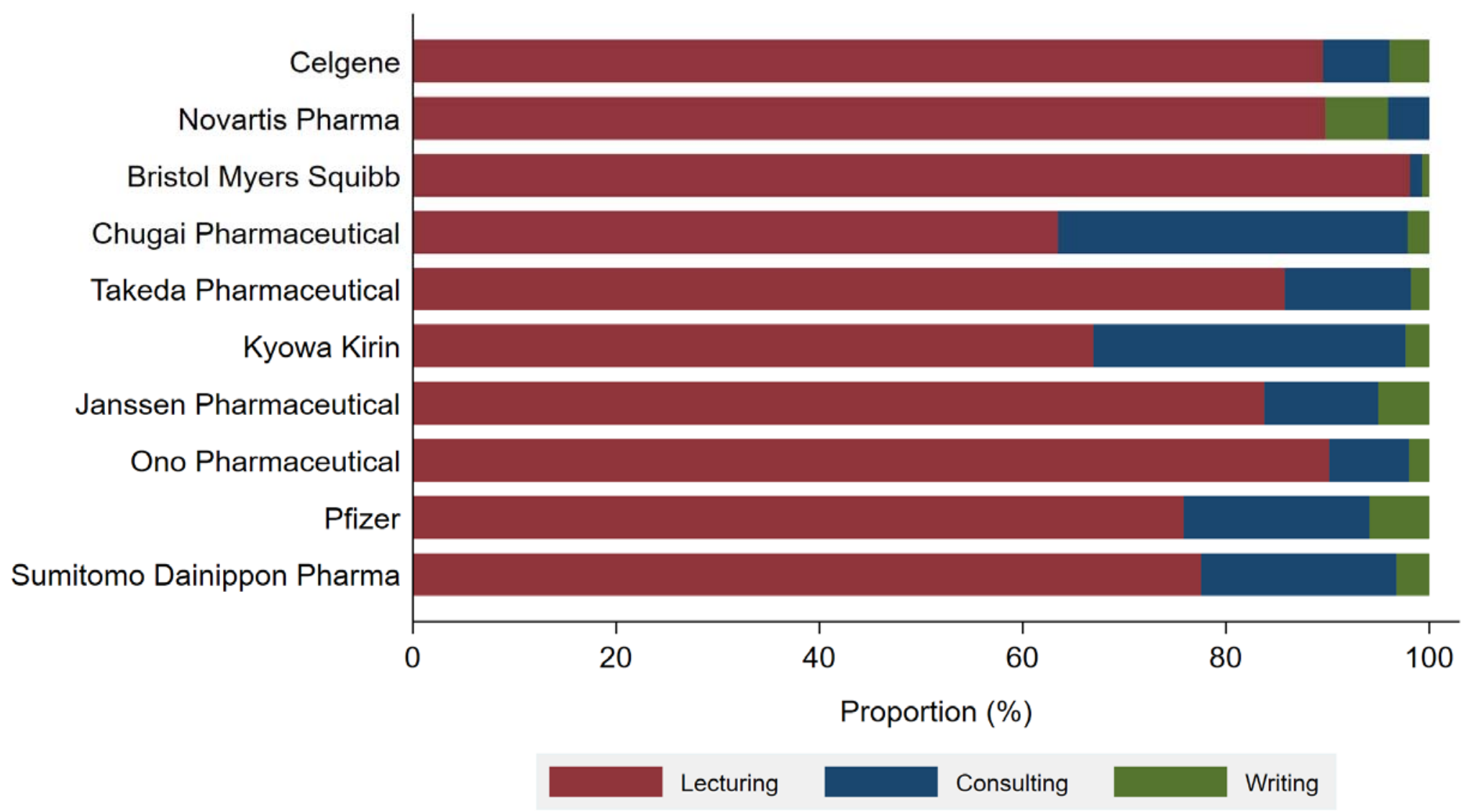

